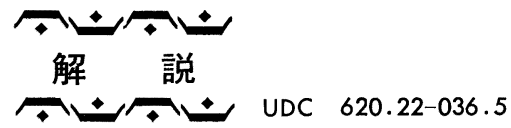

鉄鋼の競合材料としてのエンジニアリングプラスチック

島 村 昭 治*

\title{
Present Status of Engineering Plastics as a Rival to Iron and Steel
}

Shoji ShImamura

\section{1． 競合を意識するとき}

筆者は，鉄鋼競合材料としてのプラスチックと題して 意見を求められた事が, 10 年ぐらい前に 1 度ある. それ は某業界紙の経済セミナーの添えものとしてであつて, お歴々の中にまじつて，こそこそ話した記憶がある。そ の時の記録は散逸してしまつたので，どんな内容の話だ つたか定かでないが，高度成長時代の終わり頃とは言 え，まだ我々はかげりにも気付かない時であつたから， 全体が勇ましい話であり，材料代替といらことも，単な る機能面やコスト面からのそれであつて，現在のように 資源・エネルギ論，廃棄性やリサイクルを含めての議論 は少なかつたように思う。そしてその時の筆者の結論 は，プラスチックとの競合を鉄鋼はマクロには気にする 必要はないといらことであつた。 ここでいらマクロとは 鉄鋼への需要量といらことである. これに対し, ミクロ すなわち個々の鉄鋼製品の中では，すでにあるいはこれ からプラスチック化されるものは数多くある. しかし， それは朝食のバターがマーガリンに代わつたけれど, パ ンはやはりパンであるといらことで，鉄鋼関係者は関心 は持つべきであるけれど，危機感は持たなくてもよい. それは年産 1 億 $\mathrm{t}$ ベースの鉄鋼, 800 万 $\mathrm{t}$ ベースのプラ スチック，25万 $\mathrm{t}$ ベースの繊維強化プラスチック (FRP) の年産規模（現在）から考えてみるとわかる. しかし， これは重量比 (400:32:1) であつて, 容積比をとつて みると（鉄鋼，プラスチックおよび FRP の比重をそれ ぞれ 7.8, 1.2 および 1.7 とした), $87: 45: 1$ となる から，まわりを見ると，やたらにプラスチックが目に付 くので，競合といらことが頭の隅をかすめるのかも知れ ない. またプラスチック側にとつては, バターがマーガ リンに代わるといらことが重要なので，メーターケース のプラスチック化は, インスッルメントパネルのプラ化 へ，そしてフロントェンドのプラ化へと広がり，いずれ はアウターボデーのプラ化と夢をふくらませるからであ
る（前々者については大幅にプラ化されていることは周 知のとおりである) ・

さて, 10 年前の 鉄鋼界におけるプラスチックとの競 合意識は, 輪島が大学相撲から角界に入つた時の横綱の 意識のようなもので，少し気になるから様子をさぐろう という程度であつたが，最近のそれは千代の富士が関脇 (大関ではない)に上つて来た時ぐらいの関心ではないだ ろらか。

鉄鋼界が，プラスチック（この場合は主として FRP） に対してはつきり競合材料として多少の危機感を持つた のは, 1977 年に Ford がいわゆる Light Weight Vehicle Program を発表した時である。これは同年に米国 DOE が Energy Policy and Conservation Act を発表 し，乗用車の燃費規制の目標值として, 1978 年の $18 \mathrm{M}$ P G $(7.6 \mathrm{~km} / l)$ を順次高め, 1985 年には $27.5 \mathrm{MPG}$ $(11.6 \mathrm{~km} / l)$ とすることを要求し，しかも，0.1MPG 下 回るごとに生産車 1 台当たり 5 ドルのペナルティを課す と発表したことによる. 自動車の燃費向上策としては, 車の小型化(アメリカではこれがもつとも効果的), エン ジンの効率向上，空気抵抗等の走行抵抗の軽減および軽 量化があり，この中の軽量化の 1 抹段としての材料置換 に FRP の大幅採用をとり入れたのが，前述の Fordの プロジェクトである. 図1は，Ford が示した軽量化の ための主要材料代替部位を示したものであるが，これに より $300 \mathrm{~kg}$ 以上の軽量化を図り，燃費率を $7.2 \mathrm{~km} / l$ か ら $9.7 \mathrm{~km} / l$ に向上するとしている. この車の試作車 Ford LTD '79 は 1979 年 5 月に発表されたが, 表 1 に よると鋼板から GFRP(カーボン繊維強化プラスチック 一図 1 ではグラファイト強化プラスチック）への転換に より, 全体で約 $320 \mathrm{~kg}$ と所期の軽量化を達成してい る.

表 2 は, 自動車に用いられる主要素材の, 国内全需要 に占めるシェアを示したものであるが1)，いかに自動車 が工業材料の大きな消費先であるかがわかる．例えば， 


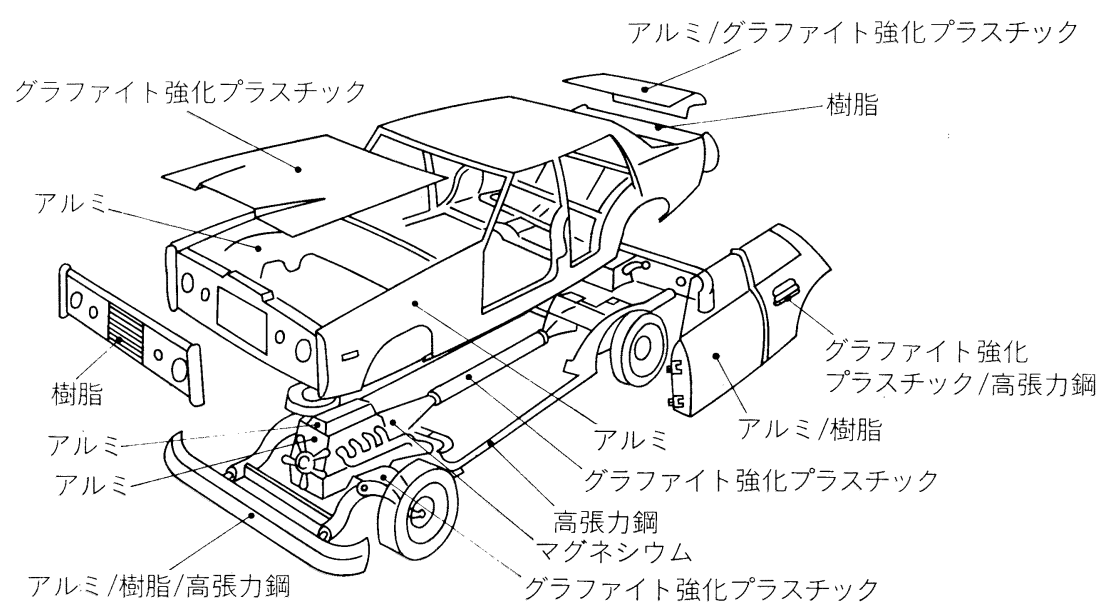

図1 Ford の材料代替案

表 1 GFRP 部材による軽量化（Ford LTD '79）

\begin{tabular}{|c|c|c|c|}
\hline 部 品名 & $\begin{array}{c}\text { 鋼の場合 } \\
(\mathrm{kg})\end{array}$ & $\begin{array}{c}\text { CFRP の場合 } \\
(\mathrm{kg})\end{array}$ & $\begin{array}{c}\text { 重量軽減 } \\
(\mathrm{kg})\end{array}$ \\
\hline 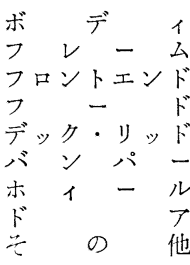 & $\begin{array}{r}208.8 \\
128.1 \\
43.5 \\
22.2 \\
19.4 \\
55.8 \\
41.7 \\
70.6 \\
81.4\end{array}$ & $\begin{array}{r}94.2 \\
93.9 \\
13.3 \\
7.6 \\
6.3 \\
20.1 \\
22.3 \\
27.7 \\
16.2\end{array}$ & $\begin{array}{r}114.6 \\
34.2 \\
30.2 \\
14.6 \\
13.1 \\
35.7 \\
19.3 \\
42.8 \\
15.2\end{array}$ \\
\hline 計 & 621.3 & 301.6 & 319.8 \\
\hline
\end{tabular}

現在の自動車ボデー外板は，ほとんど冷延鋼 板である が，これは全需要の $36 \%$ を占めており，ばね鋼にいた つては 76\% が車に向けられている. 従つて図 1 に示す ように，あるいは後述するように，ボデーやサスペンジ ョンスプリングがもし大幅に FRP 化されるとしたら, 鉄鋼界にとつて大問題である. それゆえ，プラスチック への競合意識は, 10 年前より少し真剣であるように思え る. 以下，鉄鋼とプラスチックの競合の実態あるいは可 能性といらことについて述べるが，鉄鋼はきわめて広い 応用分野を有するので，ここでは最大の需要家である自 動車を対象とし，プラスチックもエンジニアリング的機 能を有するものに限ることにする.

\section{2. エンジニアリングプラスチック}

表題に用いたエンジニアリングプラスチックは, Engineering Plastics のことであるが，この言葉本来の意味 すなわち工業用プラスチックと，プラスチックの世界で 考兄れているカテゴリーとは多少異なり, かつそのカ テゴリー自身が最近では少し（好ましい方向に）変わり つつあので, まずェンジニアリングプラスチック（以 下エンプラと略す）とは何かについて述べよう。
表 2 自動車生産用主要素材の位置づけ (1979年ベース)

\begin{tabular}{|c|c|c|c|c|}
\hline & & $\begin{array}{l}\text { 全 } \\
\text { 需要 } \\
(1000 \text { 国 } \\
(1000)\end{array}$ & $\begin{array}{l}\text { 自動車の } \\
\text { 所要量 } \\
\left(\begin{array}{ll}1 & 000 \mathrm{t})\end{array}\right.\end{array}$ & $\%$ \\
\hline 金 & 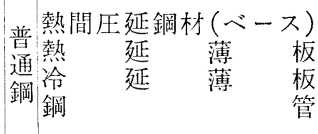 & $\begin{array}{r}78390 \\
5960 \\
11880 \\
6560\end{array}$ & $\begin{array}{r}8290 \\
1060 \\
4280 \\
390\end{array}$ & $\begin{array}{r}11 \\
18 \\
36 \\
6\end{array}$ \\
\hline 材 & 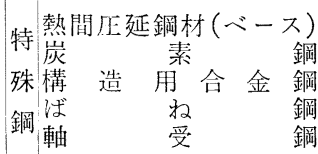 & $\begin{array}{r}11070 \\
2810 \\
2420 \\
580 \\
580\end{array}$ & $\begin{array}{r}2730 \\
1090 \\
750 \\
440 \\
130\end{array}$ & $\begin{array}{l}25 \\
39 \\
31 \\
76 \\
22\end{array}$ \\
\hline $\begin{array}{l}\text { 翡 } \\
\text { 鉄 } \\
\text { 金 } \\
\text { 属 } \\
\text { 料 }\end{array}$ & $\begin{array}{l}\text { 非銅 } \\
\text { 鉄鉛 } \\
\text { 金地 }\end{array}$ & $\begin{array}{r}1307 \\
267 \\
754 \\
2384\end{array}$ & $\begin{array}{r}110 \\
96 \\
66 \\
451\end{array}$ & $\begin{array}{r}8 \\
36 \\
9 \\
19\end{array}$ \\
\hline $\begin{array}{l}\text { 非 } \\
\text { 金 } \\
\text { 属 }\end{array}$ & 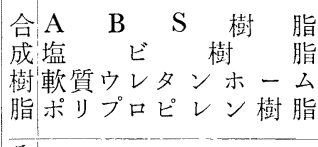 & $\begin{array}{r}302 \\
1551 \\
174 \\
1003\end{array}$ & $\begin{array}{r}79 \\
123 \\
53 \\
68\end{array}$ & $\begin{array}{r}26 \\
8 \\
30 \\
7\end{array}$ \\
\hline 料 & 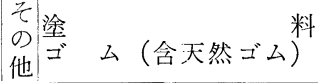 & $\begin{array}{l}2048 \\
1220\end{array}$ & $\begin{array}{l}178 \\
648\end{array}$ & $\begin{array}{r}9 \\
53\end{array}$ \\
\hline
\end{tabular}

\section{$2 \cdot 1$ エンプラとは}

エンプラといら言葉が初めて使われるよらになつたの は, 十数年前に米国 Du Pont 社が, ポリアセタール樹脂 “デルリン”を上市した時で, その意味はそれまで汎用さ れていたプラスチック（例えばポリスチレン，ポリエチ レン，塩化ビニルなど）のように日用品指向でなく, 機 械, 電気部品などの工業的用途を主とする熱可塑性プラ スチックといらことであつた. そしてポリアセタールの ほかに，前後し実用化されたポリカーボネート，PET， 
表 3 調查対象高機能樹脂の種類

\begin{tabular}{|c|c|}
\hline 非 強 化 樹 脂 & 強 化 樹 脂 \\
\hline 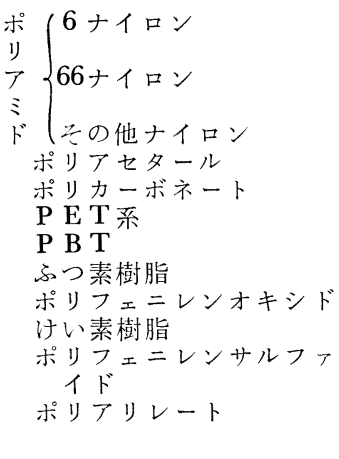 & 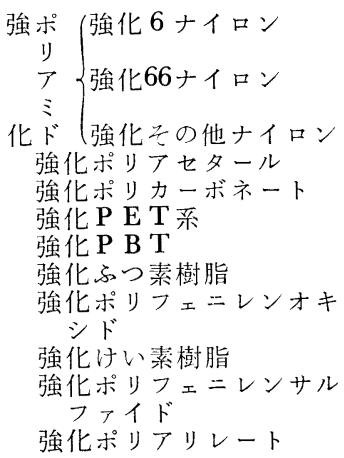 \\
\hline$\underline{-}$ & $\begin{array}{l}\text { 強化ポリプロピレン } \\
\text { 強化 A S 樹脂 } \\
\text { 強化 A B S 樹脂 }\end{array}$ \\
\hline
\end{tabular}

注）とてでいう「強化」とは, ガラス綫維, 炭素繊維, フィラー等を樹

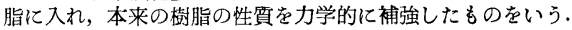

$\mathrm{PBT}$ ，シリコーン，ふつ素樹脂および既にエンジニアリ ングにもかなり使われていたナイロンなどを総称してェ ンプラと呼ぶようになつた。 しかし，これは考えてみる と，おかしい定義であつて，工業用のプラスチックとい う語義本来の意味では, 約 60 年の歴史を有するフェノ 一ル樹脂や各種の FRP もそれに含まれるし, ポリプロ ピレン (PP) なども強化品は, 例えば自動車のヒーター コアケーシングにタルク充てん PP が用いられており, これも立派なエンプラである. Du Pont でも最近は Engineering Plastics といら言葉は余り使わず，代わり に Engineering Thermoplastics といら言葉を使つてい る. Du Pont は熱可塑(thermoplastics)が主で, 熱硬化 (thermosets) は汪とんど生産していないのでこう変えた のであろらが，この方が䛊解をまねかなくてよい．

通産省基礎産業局では，エンプラが最近伸びているに もかかわらず，その実態が不明確であるとして，一昨年 53 年の需要構造調査を行い, その結果が発表されたが2), ここではェンプラの代わりに高機能樹脂といら用語が, 次のような定義で用いられている.

「汎用プラスチックに比べ, 耐熱性, 耐久性, 機械的特 性等がすぐれ, 輸送部品, 機械部品, 電機, 電子部品等 の高度な特性を要求される工業用プラスチック材料」そ して対象としてあげたものは表 3 のごとくである．この 表にみるごとく， PP, AS および ABS はそれ自体は沉 用でェンプラではないが，その強化品はェンプラと考え ている．また表中に，いわゆる FRP(正しくはFRTS)* が抜けているのは，これはすでに統計が確立しているか

* FRP（繊維強化プラスチック）は, FRTS (Fiber Reinforced Thermosets, 緎維強化熱硬化性プラスチック) \& FRTP (Fiber Reinforced Thermoplastics，繊維強化熱可塑性プラスチック）に大別さ れるが，慣用として FRP=FRTS とするととが多い.
らである．従つて本稿では，定義としては上記により， その内容としては, FRTS も含めて考えることにする.

\section{$2 \cdot 2$ 生産量と用途}

エンプラはわが国でどのくらい生産されているか，こ れは競合を考える上の第 1 歩である．前述の調査をまと めたのが表 4 である．これによると昭和 53 年の総生産

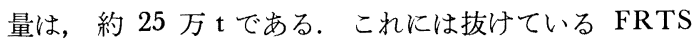
の統計が，表 5 である. 表 4,5 は用途の分け方が少し 異なるが，表 5 の雑貨も一応含めて考光ると，昭和 53 年のエンプラ全生産は約 45 万 $\mathrm{t}$ となる. そしてその樹 脂別の内訳は，内外需を含め上位 6 つをあげると，

1. FRTS (主として GRUP(ガラス繊維強化不飽和 ポリエステル)

$203910 \mathrm{t}$

2. PET 系 $67940 \mathrm{t}$

3. ポリアミド系 $59530 \mathrm{t}$

4. ポリアセタール $37510 \mathrm{t}$

5. ポリカーボネート $28990 \mathrm{t}$

6. 強化ポリプロピレン $27140 \mathrm{t}$

となつている.

次に用途別の内訳では, 表 4 の高機能樹脂に限ると上 位 5 つは次のごとくで,

$\begin{array}{ll}\text { フィルム } & 62855 \mathrm{t} \\ \text { 自動車 } & 42677 \mathrm{t} \\ \text { 電機 } & 26125 \mathrm{t} \\ \text { 電子 } & 25841 \mathrm{t} \\ \text { 容器・雑貨 } & 17365 \mathrm{t}\end{array}$

成形品としては，自動車が第 1 の用途であることがわか る.ところが表 5 に見るごとく FRTS の自動車への使 用は 53 年に打いてわずか $3000 \mathrm{t}(1.5 \%)$ である. しか し，これはわが国における需要であつて，米国では表 6 に見るごとく 1978 年の全生産量 902700 t のうち 26.5 $\%$ の $239400 \mathrm{t}$ が自動車に向けられている.このように なぜわが国において FRTS の自動車への使用比率がい ちじるしく低いかは，興味ある課題であるが，ここでは 触れない，ただし表 6 のアメリカの統計は FRP となつ ているようにFRTS だけでなくFRTP も含んでいる. アメリカの 1978 年に拈ける FRTP の生産量は約 10 万 $\mathrm{t}$ で，その $57.5 \%$ が自動車向けと言われているが3), それを表 6 から差引いても，全 FRTS 約 80 万的の ち, 約 18.2 万 $\mathrm{t}(23 \%)$ が自動車向けであり, 日本の比 率の 15 倍である.1978 年に和ける米国の自動車用 F R $\mathrm{TP}$ 約 5.8 万 $\mathrm{t}$ に対し, 日本では表 4 より約 2.3 万 $\mathrm{t}$ 弱となる（ここで弱といら表現をとつたのは，表4より PET およびその他樹脂については統計上の守秘のため 強化, 非強化が公開されていないため, 全量を強化とし て算入したからである)・これから自動車用 FRTP の日 米の比較は約 1:2 であり, FRTS における 1:15 と はいちじるしく異なる.この辺のところは，わが国にお けるこれからのエンプラと鉄鋼との競合を考える上に留 
裴 4 供給者における樹脂別，強化非強化別および用途別出荷量調査結果

(単位: $\mathrm{t}$ )

\begin{tabular}{|c|c|c|c|c|c|c|c|c|c|c|c|c|c|c|}
\hline \multirow{2}{*}{\multicolumn{2}{|c|}{ 用 途 }} & \multicolumn{3}{|c|}{ ポリアミド*1 } & \multicolumn{3}{|c|}{ ポリアセタール } & \multicolumn{3}{|c|}{ ポリカーボネート } & \multirow{2}{*}{$\left|\begin{array}{c}\mathrm{PET} \\
\text { 系 } \\
\text { 強化お } \\
\text { よび非 } \\
\text { 強化 }\end{array}\right|$} & \multicolumn{3}{|c|}{ P B } \\
\hline & & 胎 & 化 & in & & t & 計 & 強 & & 計 & & & & it \\
\hline & 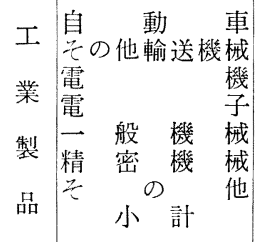 & $\begin{array}{r}2173 \\
47 \\
1572 \\
628 \\
529 \\
34 \\
24 \\
5007\end{array}$ & \begin{tabular}{rl|}
8080 \\
731 \\
3407 \\
2453 \\
1630 \\
215 \\
632 \\
17148
\end{tabular} & \begin{tabular}{rl|}
10 & 253 \\
778 \\
4979 \\
3081 \\
2159 \\
249 \\
656 \\
22155
\end{tabular} & \begin{tabular}{|r}
646 \\
0 \\
250 \\
340 \\
100 \\
0 \\
0 \\
1336
\end{tabular} & $\begin{array}{r}8694 \\
200 \\
3710 \\
8440 \\
2590 \\
1150 \\
550 \\
25334\end{array}$ & $\begin{array}{r}9340 \\
200 \\
3960 \\
8780 \\
2690 \\
1150 \\
550 \\
26670\end{array}$ & $\begin{array}{r}8 \\
2 \\
109 \\
90 \\
15 \\
48 \\
18 \\
293\end{array}$ & \begin{tabular}{rr|}
1 & 259 \\
193 \\
4567 \\
3459 \\
1326 \\
1242 \\
960 \\
13006
\end{tabular} & $\begin{array}{r}1 \\
5 \\
4 \\
1 \\
1 \\
1 \\
15\end{array}$ & \begin{tabular}{|r}
400 \\
50 \\
1200 \\
900 \\
230 \\
70 \\
0 \\
2850
\end{tabular} & $\begin{array}{rr}1 & 3 \\
1 & 7 \\
2 & 4 \\
1 \\
4 \\
1 \\
63\end{array}$ & $\begin{array}{r}130 \\
6 \\
448 \\
404 \\
113 \\
80 \\
52 \\
1233\end{array}$ & $\begin{array}{r}5 \\
15 \\
760\end{array}$ \\
\hline & 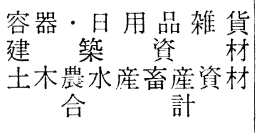 & $\begin{array}{r}112 \\
0 \\
0 \\
5119\end{array}$ & $\begin{array}{r}3247 \\
3771 \\
754 \\
24920\end{array}$ & \begin{tabular}{|r|}
3359 \\
3771 \\
754 \\
30039
\end{tabular} & $\begin{array}{r}0 \\
0 \\
0 \\
1336\end{array}$ & $\begin{array}{r}4050 \\
1220 \\
0 \\
30604\end{array}$ & $\begin{array}{r}4050 \\
1220 \\
0 \\
31940\end{array}$ & $\begin{array}{r}20 \\
0 \\
3130\end{array}$ & $\begin{array}{r}1293 \\
403 \\
35 \\
14737\end{array}$ & $\begin{array}{r}1466 \\
423 \\
35 \\
17867\end{array}$ & \begin{tabular}{|r}
6878 \\
0 \\
0 \\
9728
\end{tabular} & $\begin{array}{r}23 \\
0 \\
0 \\
6397\end{array}$ & $\begin{array}{r}84 \\
5 \\
0 \\
1322\end{array}$ & $\begin{array}{r}107 \\
5 \\
0 \\
7719\end{array}$ \\
\hline & $\begin{array}{l}\text { ト・板・合成皮革 } \\
\text { プ・継手・ホース } \\
\text { デ } \\
\text { テープその他*3 } \\
\text { 需 }\end{array}$ & $\begin{array}{r}0 \\
5119\end{array}$ & $\begin{array}{r}9597 \\
1911 \\
710 \\
5964 \\
43102\end{array}$ & $\begin{array}{r}710 \\
5964 \\
48221 \\
\end{array}$ & $\begin{array}{r}0 \\
1336\end{array}$ & \begin{tabular}{r|}
0 \\
700 \\
0 \\
0 \\
304
\end{tabular} & $\begin{array}{r}700 \\
0 \\
0 \\
32640\end{array}$ & $\begin{array}{r}4 \\
0 \\
34\end{array}$ & $\begin{array}{r}1345 \\
2066 \\
192 \\
745 \\
19085\end{array}$ & $\begin{array}{r}2066 \\
196 \\
745 \\
22219\end{array}$ & $\begin{array}{r}51240 \\
300 \\
200 \\
1770 \\
63238\end{array}$ & $\begin{array}{r}0 \\
0 \\
0 \\
6397\end{array}$ & $\begin{array}{r}0 \\
0 \\
106 \\
1428\end{array}$ & 7825 \\
\hline & 計 $^{\text {出 }}$ & & & & 476 & $\begin{array}{r}4729 \\
36033\end{array}$ & $\begin{array}{r}4869 \\
37509\end{array}$ & 3342 & $\begin{array}{r}6560 \\
25645\end{array}$ & & \begin{tabular}{|r|}
4700 \\
67938
\end{tabular} & $\begin{array}{r}50 \\
6447\end{array}$ & $\begin{array}{r}30 \\
1458\end{array}$ & 7905 \\
\hline
\end{tabular}

表 4 (つづき)

(単位: $t$ )

\begin{tabular}{|c|c|c|c|c|c|c|c|c|c|c|c|c|c|}
\hline \multirow{2}{*}{\multicolumn{3}{|c|}{ 用 }} & \multicolumn{3}{|c|}{ ふつ素 樹 脂 } & \multicolumn{3}{|c|}{ けい素 樹 脂 } & $\begin{array}{l}\text { ポリプロ } \\
\text { ピレン }\end{array}$ & A S 樹脂 & $\begin{array}{c}\mathrm{A} \text { B S S } \\
\text { 樹 脂 }\end{array}$ & \multirow{2}{*}{$\mid$\begin{tabular}{|c|} 
その他 \\
樹脂*2 \\
強化抢よ \\
び非強化
\end{tabular}} & \multirow{2}{*}{ 合計 } \\
\hline & & & 強 & 強化 & 計 & 強 & 强化 & 計 & 強 化 & 強 化 & 強 化 & & \\
\hline 成 & $\begin{array}{l}\text { 工 } \\
\text { 業 } \\
\text { 製 } \\
\text { 品 }\end{array}$ & 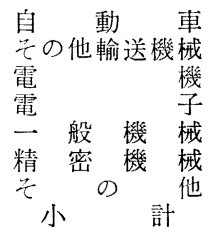 & $\begin{array}{r}42 \\
20 \\
22 \\
4 \\
57 \\
0 \\
2 \\
147\end{array}$ & $\begin{array}{r}108 \\
44 \\
254 \\
51 \\
569 \\
41 \\
26 \\
1093\end{array}$ & $\begin{array}{r}150 \\
64 \\
276 \\
55 \\
626 \\
41 \\
28 \\
1240\end{array}$ & $\begin{array}{r}4 \\
50 \\
55\end{array}$ & $\begin{array}{r}0 \\
0 \\
35 \\
0 \\
0 \\
0 \\
0 \\
35\end{array}$ & $\begin{array}{r}0 \\
0 \\
79 \\
506 \\
0 \\
0 \\
0 \\
585\end{array}$ & $\begin{array}{r}14208 \\
60 \\
4765 \\
278 \\
131 \\
235 \\
267 \\
19944\end{array}$ & $\begin{array}{r}4280 \\
0 \\
517 \\
868 \\
5 \\
0 \\
0 \\
5670\end{array}$ & $\begin{array}{r}24 \\
0 \\
674 \\
316 \\
430 \\
75 \\
9 \\
1528\end{array}$ & $\begin{array}{r}1176 \\
11 \\
1773 \\
3853 \\
1465 \\
195 \\
0 \\
8473\end{array}$ & $\begin{array}{r}42677 \\
1415 \\
26125 \\
25841 \\
9469 \\
4325 \\
2813 \\
112665\end{array}$ \\
\hline 品 & $\begin{array}{l}\text { 容 } \\
\text { 土木 }\end{array}$ & $\begin{array}{l}\text { 器 ·日用品雑貨 } \\
\text { 築 } \\
\text { 資 } \\
\text { 合水産畜産資材 } \\
\text { 計 }\end{array}$ & $\begin{array}{r}0 \\
20 \\
0 \\
167\end{array}$ & $\begin{array}{r}12 \\
245 \\
0 \\
1350\end{array}$ & $\begin{array}{r}12 \\
265 \\
0 \\
1517\end{array}$ & $\begin{array}{r}0 \\
550\end{array}$ & $\begin{array}{r}0 \\
0 \\
0 \\
35\end{array}$ & $\begin{array}{r}0 \\
0 \\
0 \\
585\end{array}$ & $\begin{array}{r}1364 \\
18 \\
35 \\
21361\end{array}$ & $\begin{array}{r}0 \\
1 \\
0 \\
5671\end{array}$ & $\begin{array}{r}30 \\
7 \\
0 \\
1565\end{array}$ & $\begin{array}{r}99 \\
0 \\
0 \\
8572\end{array}$ & $\begin{array}{r}17365 \\
5710 \\
824 \\
136564\end{array}$ \\
\hline & -1 & $\begin{array}{c}\text { ル } \\
\text { 板 } \text { 合成皮革 }\end{array}$ & $\begin{array}{r}125 \\
10\end{array}$ & $\begin{array}{r}362 \\
74\end{array}$ & $\begin{array}{r}487 \\
84\end{array}$ & ( & $\begin{array}{r}118 \\
0\end{array}$ & $\begin{array}{r}118 \\
0\end{array}$ & $\begin{array}{r}68 \\
5076\end{array}$ & $\begin{array}{l}0 \\
0\end{array}$ & $\begin{array}{l}0 \\
0\end{array}$ & $\begin{array}{l}0 \\
1\end{array}$ & $\begin{array}{l}62855 \\
10138\end{array}$ \\
\hline & & & 0 & 163 & 163 & ( & 0 & 0 & 0 & 0 & 0 & 0 & 1269 \\
\hline & & $\begin{array}{l}\text { ープその他*3 } \\
\text { 需 }\end{array}$ & $\begin{array}{r}18 \\
320\end{array}$ & $\begin{array}{r}725 \\
2674\end{array}$ & $\begin{array}{r}743 \\
2994\end{array}$ & 55 & \begin{tabular}{l|ll|}
0 & 2 & 096 \\
0 & 2 & 249
\end{tabular} & $\begin{array}{l}2096 \\
2799\end{array}$ & $\begin{array}{r}365 \\
26870\end{array}$ & $\begin{array}{r}0 \\
5671\end{array}$ & $\begin{array}{r}0 \\
1565\end{array}$ & $\begin{array}{r}0 \\
8573\end{array}$ & $\begin{array}{r}11789 \\
222615\end{array}$ \\
\hline 絰 & & $\begin{array}{l}\text { 出 } \\
\text { 計 }\end{array}$ & $\begin{array}{r}0 \\
320\end{array}$ & $\begin{array}{r}410 \\
3084\end{array}$ & $\begin{array}{r}410 \\
3404\end{array}$ & 55 & \begin{tabular}{l|r|}
0 & 138 \\
0 & 2387
\end{tabular} & $\begin{array}{r}138 \\
2937\end{array}$ & $\begin{array}{r}272 \\
27142\end{array}$ & $\begin{array}{r}61 \\
5732\end{array}$ & $\begin{array}{r}51 \\
1616\end{array}$ & $\begin{array}{r}0 \\
8573\end{array}$ & $\begin{array}{r}28661 \\
251276\end{array}$ \\
\hline
\end{tabular}

注) ${ }^{* 1}$. 6ナイロン, 66 ナイロンおよびその他ナイロン（表 3 参照）の計

*2. ポリフェニレンオキシド, ポリフェニレンサルファイドおよびポリアリレートの計

*3. 延伸テープ, ヤーン類，モノフィラメント，テグス，電線被覆，フォーム，ブレンド用，繊維・紙加工，接着剤，栥料，コーティング， ライニング, その他の計 
表 5 我が国の FRTS (主として GRUP) 用途別出荷量*

\begin{tabular}{|c|c|c|c|c|c|c|c|c|c|}
\hline 分類 & 建設資材 & 住宅機材 & 船艇 & $\begin{array}{l}\text { 辠動車 } \\
\text { 輌 }\end{array}$ & 多ンク & 工業機材 & 雑 貨 & その他 & 合 計 \\
\hline 48年 & 12700 & 94000 & 29900 & 3100 & 16200 & 14100 & 7500 & 11500 & 189000 \\
\hline $\begin{array}{c}48 \text { 年 } \\
(\text { 対前年比) } \\
\left(\begin{array}{c}\text { 占 有 率) }\end{array}\right.\end{array}$ & $\begin{array}{r}11000 \\
(87) \\
(8)\end{array}$ & $\begin{array}{r}63100 \\
(67) \\
(46)\end{array}$ & $\begin{array}{r}23800 \\
(80) \\
(18)\end{array}$ & $\begin{array}{r}2800 \\
(90) \\
(2)\end{array}$ & $\begin{array}{r}12300 \\
(76) \\
(9)\end{array}$ & $\begin{array}{r}10600 \\
(75) \\
(8)\end{array}$ & $\begin{array}{c}5200 \\
(69) \\
(4)\end{array}$ & $\begin{array}{c}7300 \\
(63) \\
(5)\end{array}$ & $\begin{array}{r}136100 \\
(72) \\
(100)\end{array}$ \\
\hline $\begin{array}{c}50 \text { 年 } \\
\text { (対前年比) } \\
\text { (占 有 率) }\end{array}$ & $\begin{array}{c}11200 \\
(102) \\
(9)\end{array}$ & $\begin{array}{r}53100 \\
(84) \\
(43)\end{array}$ & $\begin{array}{c}25600 \\
(108) \\
(21)\end{array}$ & $\begin{array}{r}2700 \\
(96) \\
(2)\end{array}$ & $\begin{array}{r}11600 \\
(94) \\
(9)\end{array}$ & $\begin{array}{r}7700 \\
(73) \\
(6)\end{array}$ & $\begin{array}{c}5500 \\
(106) \\
(4)\end{array}$ & $\begin{array}{c}6800 \\
(93) \\
(6)\end{array}$ & $\begin{array}{r}124200 \\
(91) \\
(100)\end{array}$ \\
\hline 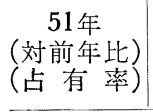 & $\begin{array}{r}12880 \\
(115) \\
(8)\end{array}$ & $\begin{array}{r}69720 \\
(131) \\
(43) \\
\end{array}$ & $\begin{array}{r}36470 \\
(142) \\
(22) \\
\end{array}$ & $\begin{array}{c}3610 \\
(134) \\
(2) \\
\end{array}$ & $\begin{array}{r}13780 \\
(119) \\
(8)\end{array}$ & $\begin{array}{r}10350 \\
(134) \\
(6)\end{array}$ & $\begin{array}{l}5700 \\
(104) \\
(4)\end{array}$ & $\begin{array}{r}11050 \\
(163) \\
(7)\end{array}$ & $\begin{array}{r}163570 \\
(132) \\
(100)\end{array}$ \\
\hline $\begin{array}{c}52 \text { 年 } \\
\text { (詨前年比) } \\
\text { (占 有率) }\end{array}$ & $\begin{array}{c}12910 \\
(100) \\
(7)\end{array}$ & $\begin{array}{r}69310 \\
(99) \\
(40)\end{array}$ & $\begin{array}{c}41080 \\
(113) \\
(23)\end{array}$ & $\begin{array}{r}3460 \\
(96) \\
(2)\end{array}$ & $\begin{array}{r}17270 \\
(125) \\
(10)\end{array}$ & $\begin{array}{c}12790 \\
(124) \\
(7)\end{array}$ & $\begin{array}{c}5450 \\
(95) \\
(3)\end{array}$ & $\begin{array}{r}13420 \\
(121) \\
(8)\end{array}$ & $\begin{array}{r}175690 \\
(107) \\
(100)\end{array}$ \\
\hline $\begin{array}{c}53 \text { 年 } \\
\text { (対前年比) } \\
\text { (占 有 率) }\end{array}$ & $\begin{array}{c}14550 \\
(113) \\
(7.1)\end{array}$ & $\begin{array}{r}75730 \\
(109) \\
(37.1) \\
\end{array}$ & $\begin{array}{l}53130 \\
(129) \\
(26.1)\end{array}$ & $\begin{array}{r}3020 \\
(87) \\
(1.5)\end{array}$ & $\begin{array}{c}19960 \\
(116) \\
(9.8)\end{array}$ & $\begin{array}{c}15040 \\
(118) \\
(7.4)\end{array}$ & $\begin{array}{l}7140 \\
(131) \\
(3.6)\end{array}$ & $\begin{array}{c}15340 \\
(114) \\
(7.5)\end{array}$ & $\begin{array}{r}203910 \\
(116) \\
(100)\end{array}$ \\
\hline $\begin{array}{c}\text { 54年 } \\
\text { (推定) }\end{array}$ & 18900 & 84600 & 62300 & 3600 & 26500 & 19700 & 9000 & 21100 & 245700 \\
\hline
\end{tabular}

* 出荷量 $:$ 対前年比, 占有率：(\%) （社)強化プラスチック技術協会による。

表 6 米国の F R P 用途別出荷実績と予測*

\begin{tabular}{|c|c|c|c|c|c|c|c|}
\hline \multicolumn{2}{|c|}{ 市 } & \multicolumn{2}{|c|}{ 1978(実績) } & \multicolumn{2}{|c|}{ 1979（推定） } & \multicolumn{2}{|c|}{ 1980(予測) } \\
\hline 1 & 陸 上 輸 送 & 239.4 & $\begin{array}{l}100 \\
26.5\end{array}$ & 247.5 & $\begin{array}{l}103 \\
26.9\end{array}$ & 234.9 & $\begin{array}{l}98 \\
26.9\end{array}$ \\
\hline 2 & 舟 艇 - 船 舶 & 193.5 & $\begin{array}{l}100 \\
21.4\end{array}$ & 173.25 & $\begin{array}{l}90 \\
18.8\end{array}$ & 153.9 & $\begin{array}{l}80 \\
17.7\end{array}$ \\
\hline 3 & 築 & 145.35 & $\begin{array}{l}100 \\
16.1\end{array}$ & 150.75 & $\begin{array}{l}104 \\
16.4\end{array}$ & 144.0 & $\begin{array}{l}99 \\
16.5\end{array}$ \\
\hline 4 & 耐 & 97.2 & $\begin{array}{l}100 \\
10.8\end{array}$ & 10 & $\begin{array}{l}110 \\
11.6\end{array}$ & 101.7 & $\begin{array}{l}105 \\
11.7\end{array}$ \\
\hline 5 & 電 & 76.5 & $\begin{array}{c}100 \\
8.5\end{array}$ & 81.0 & $\begin{array}{c}106 \\
8.8\end{array}$ & 81.9 & $\begin{array}{l}107 \\
9.4\end{array}$ \\
\hline 6 & 家電·事 務 器 & 55.35 & $\begin{array}{c}100 \\
6.1\end{array}$ & 58.5 & $\begin{array}{c}106 \\
6.3\end{array}$ & 58.5 & $\begin{array}{c}106 \\
6.7\end{array}$ \\
\hline 7 & 一 般 消 費 & 52.2 & $\begin{array}{c}100 \\
5.8\end{array}$ & 56.7 & $\begin{array}{c}109 \\
6.2\end{array}$ & 51.3 & $\begin{array}{l}98 \\
5.9\end{array}$ \\
\hline 8 & その他・特 殊 & 33.3 & $\begin{array}{c}100 \\
3.7\end{array}$ & 35.55 & $\begin{array}{c}107 \\
3.9\end{array}$ & 34.65 & $\begin{array}{l}104 \\
4.0\end{array}$ \\
\hline 9 & 航 & 9.9 & $\begin{array}{c}100 \\
1.1\end{array}$ & 10.35 & $\begin{array}{c}105 \\
1.1\end{array}$ & 10.8 & $\begin{array}{c}109 \\
1.2\end{array}$ \\
\hline & 合 & 902.7 & $\begin{array}{l}100 \\
100\end{array}$ & 920.7 & $\begin{array}{l}102 \\
100\end{array}$ & 871.65 & $\begin{array}{r}97 \\
100\end{array}$ \\
\hline * & 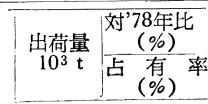 & & 蚛1 & プラスチ & 1 & & \\
\hline
\end{tabular}

意しなければならないところである.

\section{$2 \cdot 3$ 強化エンプラの特性}

現在では，プラスチックの各種特性，エンプラの特長 等については，すでにいろいろのデータが発表されてい るので, ここでは, 強化ェンプラしかも比較的最近実用 化されているもの（ただし FRTP のみ）の特性をまと めて表 7 に示した³.

\section{3. 鋼からの転換}

\section{1 自動車と材料}

$3 \cdot 1 \cdot 1$ 自動車に和将る材料構成

困 2.A はわが国の $1600 \mathrm{cc}$ クラスの自動車におけ る使用材料の重量比の 1 例を示したものであるが4)，鉄 鋼が $3 / 4$ 強を占めている. しかし図 3 に見るごとく, プ ラスチックの使用比率は鋼板の横ばいに比べて年々漸増 を続け，車種にもよるが現在では 4 6\%, 平均 $5 \%$ を占 めている1). ある予測によると，このプラスチック化は 今後もすすめられて, 1990 年には $9 \%$ に達するだろらと 言われている．しかし，競合をらんぬんするには，どの 部位にどのよらなプラスチックが使われているかが重要 なのである，図2, B は A に示したプラスチックの内訳を 示したものであるが, PP(ポリプロピレン), PU, PVG, $\mathrm{PE}, \mathrm{ABS}$ の順となつている. 表 8 は米国車とヨーロッ パ車に打ける数字である4). 図 $2, \mathrm{~B}$ と表 8 を比べて特長 的なのは表 8 でいずれも 4 位を占めているポリェステル （主としてガラス繊維強化不飽和ポリェステル，GRUP） 
表 7 強化エンジニアリングプラスチック（FRTP のみ）の特性

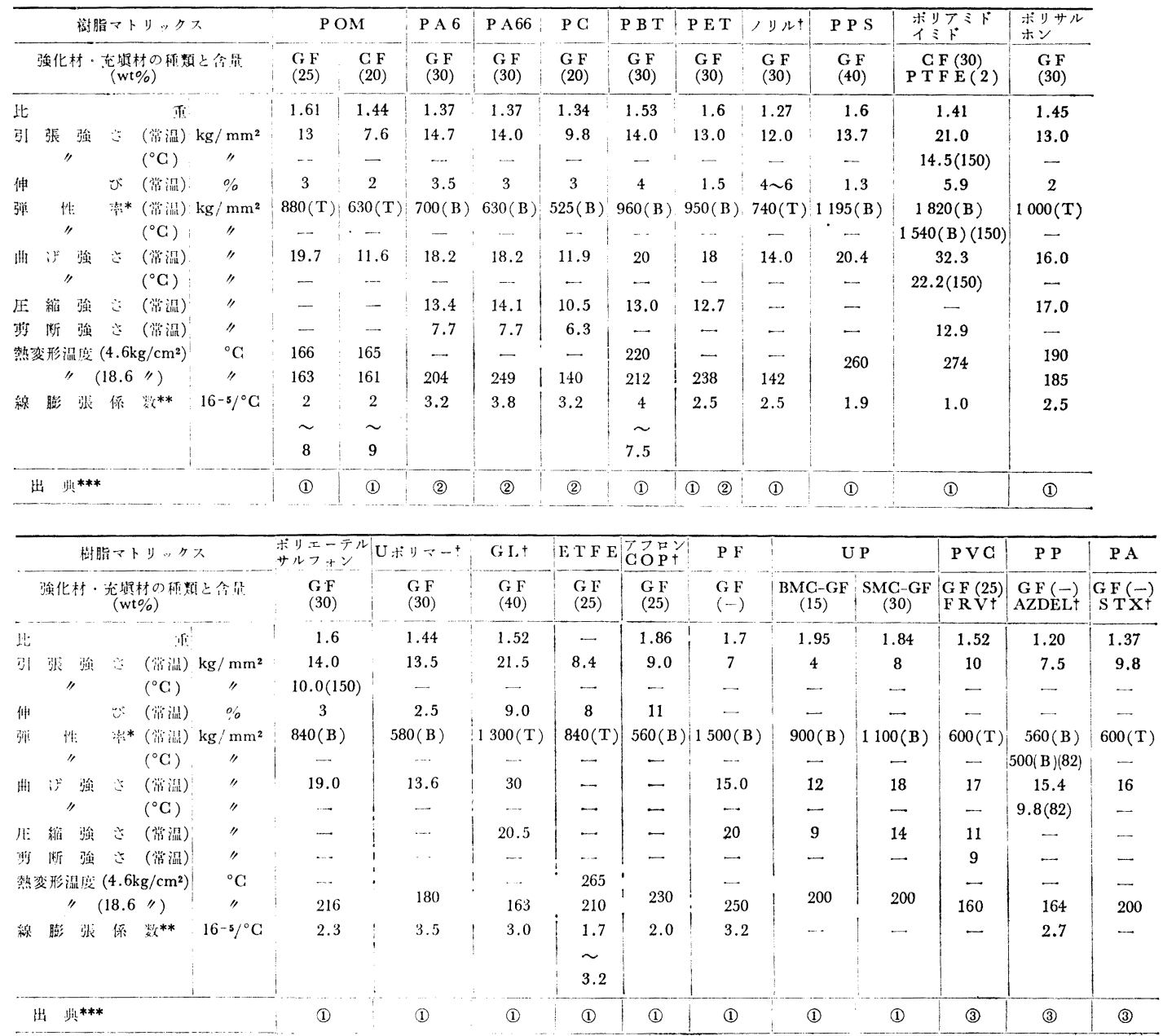

* ( T) : 引張り, (B) : 曲げ, ** おおむね流動方向の值, 〜は流動方向と直角方向との変動を示す.

***(1)プラスチックス, 1979-9, (2)機械工学便筧(6版), 5-163, (3)各社カタログ等. †商品名.

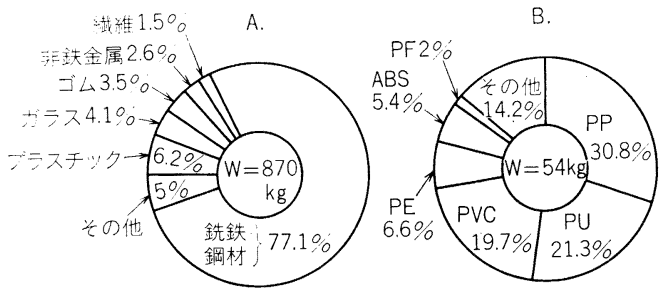

(PP : ホリプロピレン, PU：ポリウレタン, PVG : ポリ塩化ビニル, $\mathrm{PE}$ : ポリェチレン, $\mathrm{ABS}$ : アクリロニトリル・ブダジェン・スチレン 樹脂, PF : フェノール樹脂)

図 2 小型車 $(1.6 l)$ の材料構成

が，図 2,B のわが国のデータではその他に入つている ことである.これについては $2 \cdot 2$ です指摘した。図 2 , B あるいは表 7 に上位を占めている PVG および PUは 現在主としてシート材，クッション材として用いられて

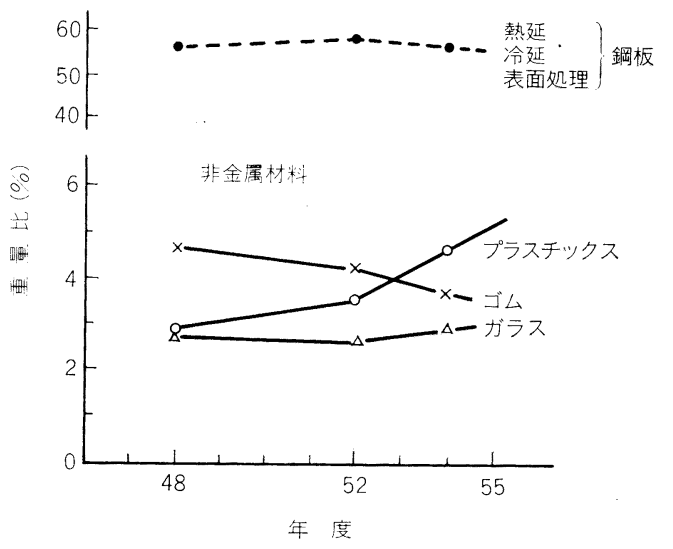

図 3 国産小型・普通乗用車原材料重量比率変化 
表 8 自動車のプラスチック使用量（1978年型）

\begin{tabular}{|c|c|c|c|c|}
\hline & $\begin{array}{l}\left.\gamma^{X} \times\right) \\
(1.7 \mathrm{t}\end{array}$ & $\begin{array}{l}\text { 力 } \\
\text { 車) }\end{array}$ & $\begin{array}{l}\exists-\square \\
(1.2 \mathrm{t}\end{array}$ & 車) \\
\hline 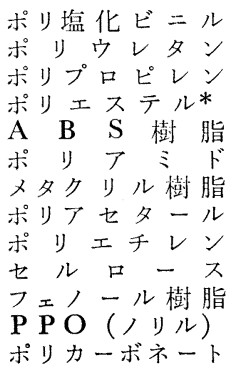 & $\begin{array}{l}13.5(\mathrm{~kg}) \\
21.6 \\
15.3 \\
14.4 \\
9.0 \\
3.6 \\
1.8 \\
1.8 \\
3.6 \\
1.8 \\
1.8 \\
0.9 \\
0.9\end{array}$ & $\begin{array}{l}15(\%) \\
24 \\
17 \\
16 \\
10 \\
4 \\
2 \\
2 \\
4 \\
2 \\
2 \\
1 \\
1\end{array}$ & $\begin{array}{l}15.4(\mathrm{~kg}) \\
15.4 \\
8.4 \\
7.7 \\
7.0 \\
4.2 \\
2.1 \\
2.1 \\
2.1 \\
2.1 \\
2.1 \\
0.7 \\
0.7\end{array}$ & $\begin{array}{l}22(\%) \\
22 \\
12 \\
11 \\
10 \\
6 \\
3 \\
3 \\
3 \\
3 \\
3 \\
1 \\
1\end{array}$ \\
\hline
\end{tabular}

$90.0(\mathrm{~kg}) 100(\%) 70.0(\mathrm{~kg}) 100(\%)$

* 主としてGRUPと思われる。

おり，エンジニアリング的用途とは言えないＰP はと れ自体は汎用プラスチックでェンブラではないが，最近 では強化品として，自動車に多く用いられるようになつ た。例えば表 4 より自動車用に向けられたエンプラを樹 脂別に分けてみると次のごとくなる（○内は順位）二小

$\begin{array}{lrlll}\text { ポリアミド (非, 強) } & 10253 \mathrm{t} & (24.0 \%) & \text { (2) } \\ \text { ポリアセタール (非, 強) } & 9340 \mathrm{t} & (21.9 \%) & \text { (3) } \\ \text { ポリカーボネート (非, 強) } & 1342 \mathrm{t} & (3.1 \%) & \text { (6) } \\ \text { PET 系 (非, 強) } & 400 \mathrm{t} & (0.9 \%) & \text { (8) } \\ \text { PBT (非, 強) } & 1504 \mathrm{t} & (3.5 \%) & \text { (5) } \\ \text { ふつ素樹脂 (非, 強) } & 150 \mathrm{t} & (0.4 \%) & \text { (9) } \\ \text { ポリプロピレン (強) } & 14208 \mathrm{t} & (33.3 \%) & \text { (1) } \\ \text { ABS 樹脂 (強) } & 4280 \mathrm{t} & (10.0 \%) & \text { (4) } \\ \text { AS 樹脂 (強) } & 24 \mathrm{t} & (0.1 \%) & \text { (1) } \\ \text { その他 (非, 強) } & 1176 \mathrm{t} & (2.8 \%) & \text { (7) } \\ \text { 計 } & 42677 \mathrm{t} & (100 \%) & \end{array}$

\section{2 転換とその理由}

前述の高機能樹脂需要構造調査では, 幸い各需要につ いて樹脂化の例と, 前の使用材料拈よび転換の理由を調 べているので，それより鋼からの転換例をピックアップ してまとめたのが表 8 である。表 9 亿は新しく採用また は代替した理由を原材料費ダウンからその他まで 15 あ げてあり，表 9 には欠足している項目もあるが，○印を 付いたものをまとめてみると次のごとくなる.

\begin{tabular}{|c|c|c|}
\hline 原材料費ダウン & 7 & $(8.1 \%)$ \\
\hline 成形加工組立費ダゥン & 28 & $(32.6 \prime \prime)$ \\
\hline デザインの自由性 & 2 & $(2.3 \prime \prime)$ \\
\hline 軽量化 & 32 & $(37.2 \prime \prime)$ \\
\hline 機械的特性 & 2 & $(2.3 \prime \prime)$ \\
\hline 摩擦, 摩耗特性 & 1 & $(1.2 \prime \prime)$ \\
\hline 耐久性, 耐候性, 疲労性 & 1 & $(1.2 " \prime)$ \\
\hline 熱的特性 & 2 & $(2.3 \prime \prime)$ \\
\hline 耐薬品性, 耐腐食性 & 2 & $(2.3 \prime \prime)$ \\
\hline 電気的性質 & 1 & $(1.2 \%)$ \\
\hline
\end{tabular}

$$
\begin{array}{lc}
\text { その他品質向上 } & 8(9.3 \prime \prime) \\
\text { 合計 }(\text { の゙゙) } & 86(100.0 \prime \prime)
\end{array}
$$

上から分かるように, 鉄鋼からェンプラ化への最大の 理由は軽量化で, 第 2 は成形加工組立費のダウンがそれ 飞続く．金属部品のプラ化の利点の一つとして部品一体 化 (parts consolidation) があげられているが、それはそ のまま組立費のダウンにつながるわけである. 上の整理 では，原材料費のダウンがそれらに続いているが，これ は恐らく成形・加工費のダウンと組み合わせて考兄られ ているのではないかと思う．表 10 は鋼を基準とし，こ れと曲げ岡性あるいは曲げ強さ（モーメント）を同じと するような各種材料の厚さを求め，それらを基にして， 各材料の比較を行つたものであるが，このよらな材料と しての単純比較によれば，鋼からのブラ化により，

(1) 厚くなる,

(2) 軽くなる,

(3) 高価になる,

ことが分かる。（1）については設計上のくふう（例总ば リブを入れる等）に上りカバーし，（3）は成形加工組立 費のダウンによりカバーされることにより，プラ化への 道は開ける.プラ化の効果として $(2)$ が大きいことは以 前からよく知られていたが， $1 \mathrm{~kg}$ の軽量化の効果を数 十万円と評価する宇宙, 数万円とする航空と異なり, 数 百円にも評価しなかつた自動車では, 軽量化による効果 は, なかなか認められなかつた。 しかし上述のごとく最 近では自動車メーカーは軽量化を最大の理由としてェン プラを採用している．それは省エネ時代を迎えて1にの べた燃費率の向上が至上目標となり，その対象として軽 量化がきわめて有効であり，その手段としてプラ化の効 果が再認識されたからである.

\section{$3 \cdot 3$ 軽量化と省エネルギ}

車を軽くしたら，ぞれだけガソリンが節約されるか． これについてはいろいろの試算があり, その幅も広いが, 1 例を示そ弓．図 4 は車の重量 $(\mathrm{kg})$ と燃費率 $(\mathrm{km} / \mathrm{l})$ との関係を1976 年モデル車について示したものである

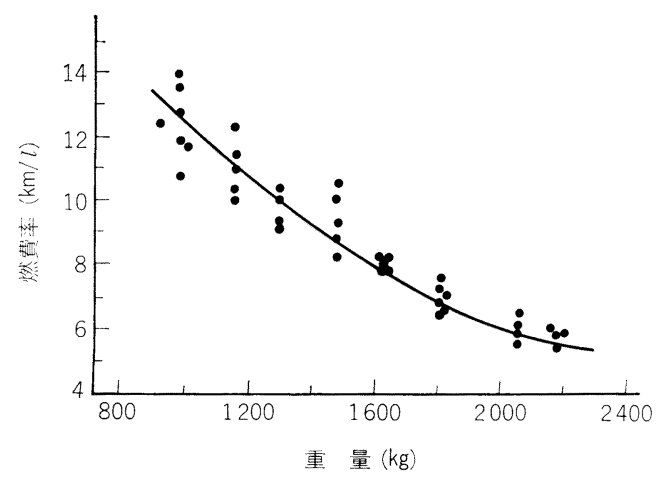

図４1976年モデル車の重量と燃費率 
表 9 自動車における材料転換の状況

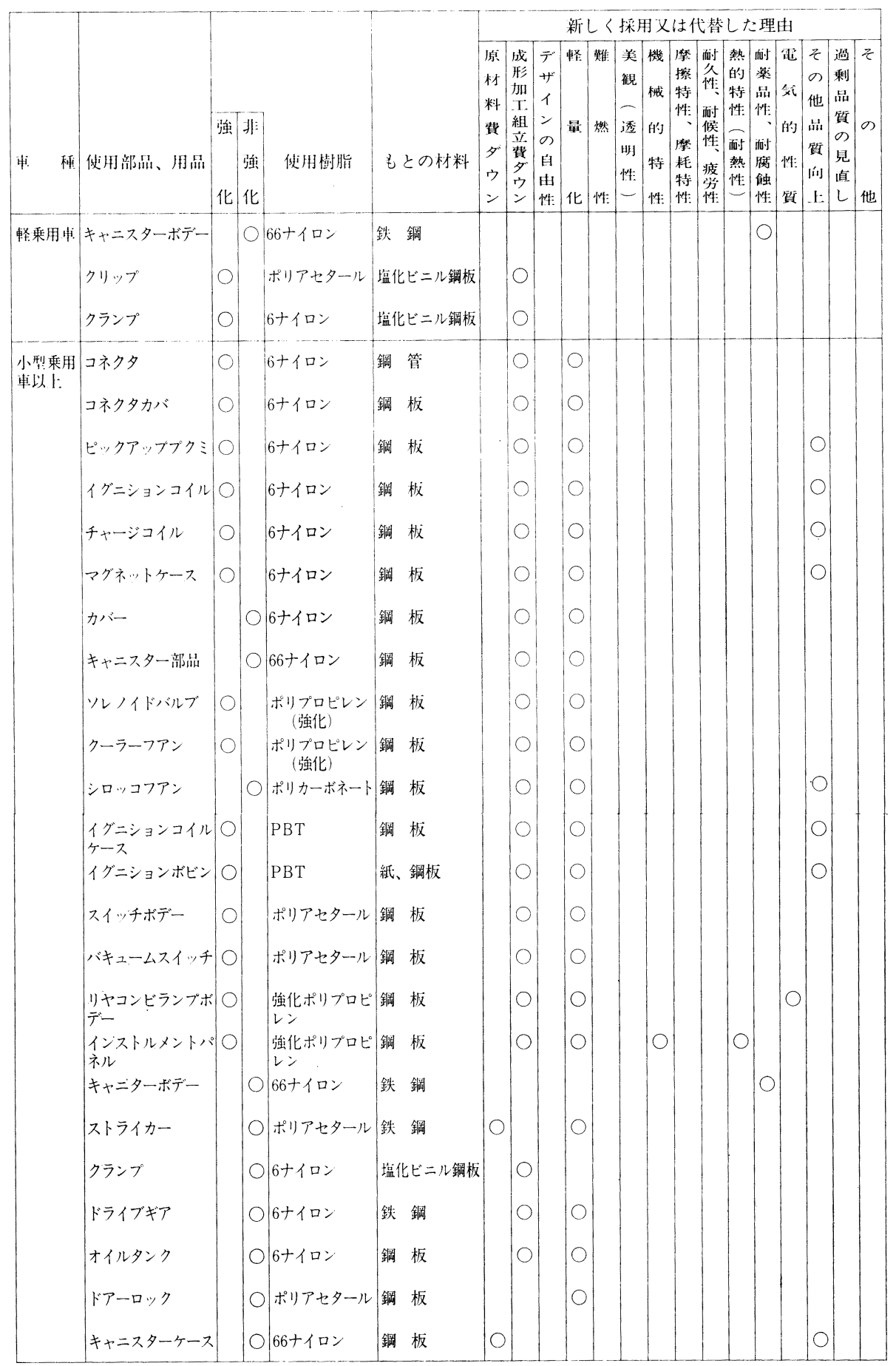




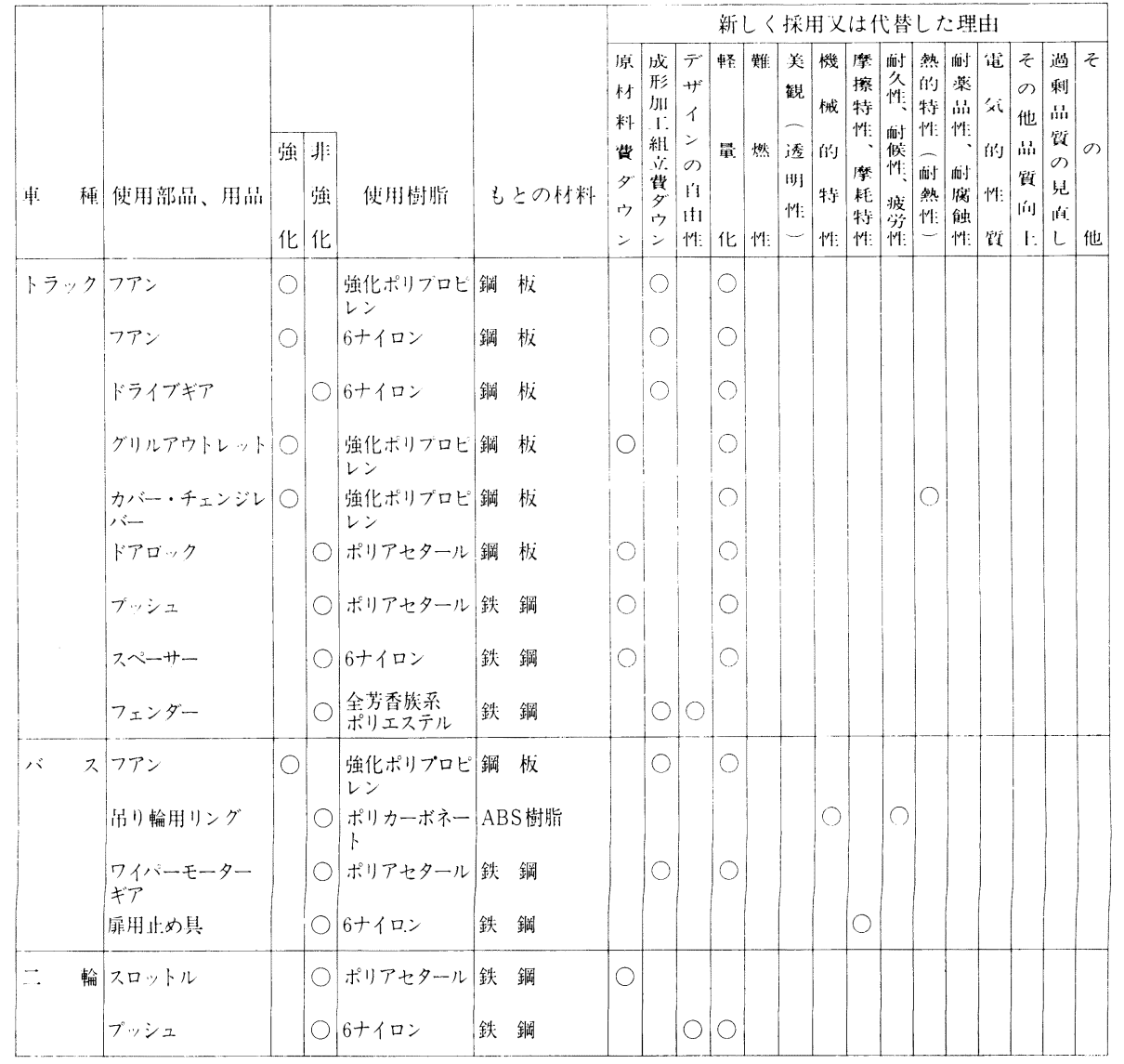

表 10 各稙 材 料の比較

\begin{tabular}{|c|c|c|c|c|c|c|c|c|}
\hline 項 & 鋼 & $\mathrm{Al}$ 合金 & A B S & P P & F R P $(\mathrm{H})$ & F R P (L) & 合 & 板 \\
\hline 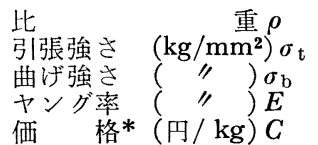 & $\begin{array}{c}7.8 \\
28 \\
40 \\
21000 \\
50\end{array}$ & $\begin{array}{c}2.7 \\
20 \\
30 \\
7200 \\
530\end{array}$ & $\begin{array}{l}1.05 \\
5.0 \\
7.0 \\
280 \\
220\end{array}$ & $\begin{array}{l}\quad 0.91 \\
3.5 \\
4.2 \\
110 \\
150\end{array}$ & $\begin{array}{c}1.7 \\
20 \\
30 \\
1600 \\
350\end{array}$ & $\begin{array}{l}1.6 \\
10 \\
15 \\
000 \\
250\end{array}$ & & \\
\hline
\end{tabular}

$\mathrm{R}_{\mathrm{t}}:$ 厚 剛さ性比

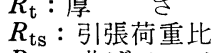

$R_{\mathrm{bs}}:$ 曲げモーメント比 $\dagger$

$R_{\mathrm{w}}:$ 重 量 比

$R_{\mathrm{c}}:$ 価 格 比 $\begin{array}{llllllllllll}1 & (0.52) & 1 & (0.18) & 1 & (0.15) & 1 & (0.12) & 1 . & (0.21) & 1 & (0.85)\end{array}$

$1.43(1.15) \quad 4.23(2.39) \quad 5.78(3.09) \quad 2.37(1.15) 2.77(1.63) \quad 4.2(2.46)$

$\begin{array}{lllllllll}1.43(0.82) & 0.76(0.43) & 0.7 & (0.39) & 1.68(0.82) & 1 & (0.58) & 0.88(0.52)\end{array}$

$\begin{array}{llllll}2.03(1) & 3.2(1) & 3.65(1) & 4.18(1) & 2.88(1) & 2.94(1)\end{array}$

$0.51(0.4) 0.6(0.32) 0.7(0.36) 0.52(0.25) 0.58(0.33) 0.33(0.21)$

$5.4(4.24) 2.64(1.41) 2.1(1.08) 3.64(1.75) 2.9(1.65) 1.59(1.01)$

$D=E_{\mathrm{t}}{ }^{3} / 12, R_{\mathrm{t}}=\sqrt[3]{E_{\mathrm{s}} / E_{\mathrm{x}}}, R_{\mathrm{w}}=R_{\mathrm{t}}\left(\rho_{\mathrm{x}} / \rho_{\mathrm{s}}\right), R_{\mathrm{c}}=R_{\mathrm{w}}\left(C_{\mathrm{x}} / C_{\mathrm{s}}\right), R_{\mathrm{ts}}=R_{\mathrm{t}}\left(\sigma_{\mathrm{tx}} / \sigma_{\mathrm{ts}}\right), R_{\mathrm{bs}}=R_{\mathrm{t}}{ }^{2}\left(\sigma_{\mathrm{bx}} / \sigma_{\mathrm{bs}}\right)$
$(\mathrm{PP}:$ ポリプロピレン, FRP $(\mathrm{H}), \operatorname{FRP}(\mathrm{L}):$ それそれ高級, 並級のガラス織維強化プラスチック $)$

* 原料価格（1973年） †）は曲げモーメントを同一にした場合

が5), この図からこれからの車の中心になると思われる 重量 $1200 \mathrm{~kg}$ 程度の車について推定してみると, $1 \mathrm{~kg}$ の軽量化は $0.01 \mathrm{~km} / l$ の燃費率の向上につながるとい らことになる. 今このクラスの車の 全走行距離を 15 万 $\mathrm{km}$ とし, 燃費率を $15 \mathrm{~km} / l$ とすれば, $1 \mathrm{~kg}$ の軽量化
により 15 万 $\mathrm{km}$ 走行中に $6.7 l$ のガソリンが節約さ れることになる. 別の試算として，車を $10 \%$ 軽くする と然費率は $10 \%$ 向上するというデータもあるが，これ を上の例にあてはめると, $0.0125 \mathrm{~km} / l$ となり, 約 $10 l$ $/ \mathrm{kg}$ の省ガソリンとなる.な撮近の発表では鋼部品の 
$\mathrm{Al}$ 化および FRP 化による軽量化ならびに省エネルギ を次のように計算している6).

\begin{tabular}{|c|c|c|}
\hline & 鋼 & $\mathrm{Al}$ \\
\hline 部品重量 (lb) & 13 & 5 \\
\hline 材料・部品製造エネルギ (gal) & 3 & 6 \\
\hline 5 年間走行エネルギ（gal） & 11 & 4 \\
\hline エネルギ合計 & 14 & 10 \\
\hline
\end{tabular}

これから鋼の FRP 化により重量が $7 \mathrm{lb}$ 減少し,エネル ギも走行用のみとして $6 \mathrm{gal}$ ，製造エネルギを含めた合 計では $7 \mathrm{gal}$ 省エネルギになるとしている，従つて 1 $\mathrm{gal} / \mathrm{lb}(8.4 \mathrm{l} / \mathrm{kg})$ が鋼 $\rightarrow \mathrm{FRP}$ に打ける省エネルギの大 きめの值と考㝋てよい（データソースが FRP 側である ので，多少のひいき目のあることを考慮した）・今ガりリ ンの価格を $¥ 150 / l$ とすれば， $1 \mathrm{~kg}$ の軽量比は， ¥ 1260 の值打ちがあるといらことになろう。これを控え 目にとつて，¥ $1000 / \mathrm{kg}$ が軽量化の成否の一つの目安 となる.最近の日米複合材料会議で鋼・GREP（ガラ 又繊維強化エポキシ樹脂）混成ばねについて発表した DAUGHERTY ${ }^{7)}$ は, 車 (この場合はトラック) の軽量化効 果を $\$ 2 \sim 3 / \mathrm{lb}$ (¥970〜1450/kg) とのべていたから， $¥ 1000 / \mathrm{kg}$ は一つの妥当な目安と考光られる。

サスペンジョンスプリングは, 自動車に打ける重要部 品の FRP 化の代表として, 最近内外のメーカーに括い てもつとも熱心に検討されているものである。図 5 は米 国 GM 社のシボレー“コルベット”に打兴後輪サス ペンジョンスプリングの FRP(GREP) 化のプロジェク トである ${ }^{8)}$. 報告によると図 5 の上に示す従来の鋼製 7

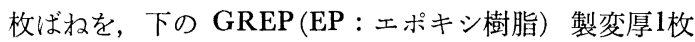
ばねに変えることにより，45 lb から $8 \mathrm{lb}$ へと $82 \%$ の 軽量化が達成され，このばねを 1981 年モデルから採用 するとのべている．実は筆者らは今から 10 年以上前に 乗用車のサスペンジョンスプリングの FRP (GREP) 化 を試みている9)。 その場合はダットサンブルーバード (旧型) の後輪用 3 枚ばねを変厚 1 枚ばねとしたのであ るが，これにより $8.2 \mathrm{~kg}$ から $1.8 \mathrm{~kg}$ へと $78 \%$ の軽 量化に成功した。しかし当時のこのばねに対する批判は コストアップで，鋼製に比べて約 1500 円高くなると予 想された。 しかし，現時点で考学ると上述の $6.4 \mathrm{~kg}$ の 軽量化による省ガソリンは $¥ 6400$ と考光てよいから， 約 $¥ 5000$ のプラスとなり，十分プラ化の意義がある のである. 前述の DAUGHERTY の例（4 枚重ね板ばねの らち，もつとも長く目玉のあるメインリーフは鋼のまま とし，他の 3 枚を GREP 化した）でも, $90 \mathrm{lb}$ から 40 $1 \mathrm{~b}$ へと $65 \%$ の軽量化が達成され，最近のわが国の試作 例でも, $8.3 \mathrm{~kg}$ から $2.0 \mathrm{~kg}$ と $76 \%$ 軽量化している10), 後者の例は， $\mathrm{CF}$ と GF のハイブリッドで作られ，リ ーフそのものは GF の及に比べ,さらに軽量化される が，FRP 化のむずかしい目玉の部分を鋼としているた め上記の值にとどまつている。
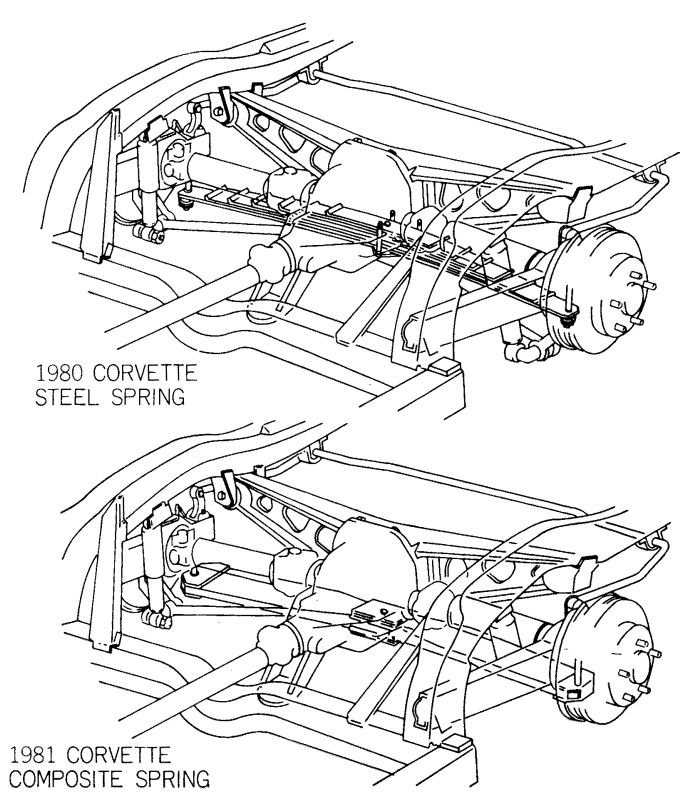

図 5

\section{4. これからの競合}

金属をプラ化する時の利点としてあげられるものは，

(1) 軽量化できる

（2）部品 1 体化が可能

（3）耐薬品性，装飾性等の機能性の向上

(4) 意匠設計の自由度 (design flexibility) の向上 などがあげられるが，前述の高機能樹脂調查における自 動車の例でも，（1)，(2)，(3)がこの順で認められて いるが，（4)が低位であつたのは意外であつた．この中 で, 従来から知られていたが，その効果をプラ化の第 1 目標としてあげてくるよらになつたのが軽量化で，これ はすでにのべたよらに省ガソリンの要求からである ${ }^{11)}$. 従つて今後の自動車分野に怙ける鉄鋼とエンプラの競合 は，軽量化の可能性とその総合効果といらことになろう が，自動車ではもら一つ競合要因がある。それは安全性 の向上で, 例壳ば米国では $5 \mathrm{mile} / \mathrm{h}$ の衝突で安全機能 部品に損傷が無いことが要求されており (FMVSS No. 215)，そのため従来の鋼製バンパに代えて，PU あるい はPP などのプラスチックバンパを採用している車が増 党つつる ${ }^{12)}$. バンパの設計あるいは採用するプラスチ ックとその成形方法は変わつて行くが，プラ化のすう勢 は変わらないと思ら。

このように，(1)省ガソリンのための軽量化，(2)部品一 体化による材料, 成形, 加工，組立を含めたコストダウ ンおよび(3)法規制による安全性の向上を 3 つの加速要素 として，今後も自動車材料に打けるプラ化は進められて 
行くが，その水準は，現在の 5\% (重量比)から, 1990 年 までの 10 年間に $10 \%$ 亿達するといらのが，大き目の 予想である，そして今後は，従来よりも強度要素の大き い部材，とくに外装部品への適用が検討されよう。それ はこの分野が，とくに(1)の軽量化への効果が大きいから である.

鉄鋼と競合するような強いエンプラが，今後自動車に ぞのくらい伸びるか.これは予想のむずかしいところで あるが，広義の強化エンプラすなわち FRTS と FRTP との使用量が 80 年代の後半には 10 万 $\mathrm{t}$ に達するである らという予想がある ${ }^{13)}$.これはFRTS については少し 希望的観測をまじえた数字であるが，この中で，表 2 の 冷延鋼板とばね鋼との和 472 万 $\mathrm{t}$ と競合するのはFRTS

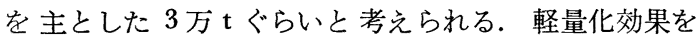
約 30\% と見れば, FRTS 3 万 t は約4万 $\mathrm{t}$ の鉄鋼となる から，472 万 $\mathrm{t}$ に対し $1 \%$ に満たない数字である. 従つ て鉄鋼側としては気にしなくてょい量であるが，FRP 側としては全生産の 2 桁の \% に乗る数字で大きな目標 なのである.

鉄鋼 120 年 (ベッセマーから) プラスチック 60 年の 工業化の歴史の差を考光ると, 鋼は耕しつくされた技術 であり，プラスチック技術はまだまだ未踏の高峯をたく さん持つている．その第 1 はリサイクルである. 鉄鋼が 技術的には完全に, 社会的にもかなりの比率でリサイク ルされているにもかかわらず，プラスチックではポリエ チレン等の 1 部が再生利用されているにすぎず, 他のプ ラスチックでは技術的にも未確立であり, 社会的にはゼ ロに近い，とくにェンプラはリサイクルしにくい性格を 有している. 第 2 はプラスチックは廃品となつても, 燃 料として大きなエネルギを保有しているといらことであ る. 現在のプラスチックは, 有害ガスや異臭の発生など でそのまま然料として使えないが，もしこれが可能とな れば石油という残り少ない資源をまずプラスチックとし て, 次燃料として使うことになり，高度利用技術とし てこれに過ぎるものはない、リサイクルできるか，ある いは燃料として再利用できるェンプラ一ここが実用化 された暁こそ，エンプラが鉄鋼の競合材料として自立す
る時であろら。

それまでの，そして現在の鉄鋼とエンプラとの関係 は，互いに補完し合う所淿る。鉄鋼のすぐれているの は強度であり, エンプラのすぐれているのは機能であ る. 一方, 従来ややもすれば強度と機能を分離して考兄 ていた設計を一体化させようといらことが，省資源，省 エネルギ的立場から強く進められている. 複合材料はそ れにもつともふさわしい材料であるが，その前に，エン プラの機能と, 鉄鋼の強度とを補完的に活用する混成材 料 (composite でなく compound といら意味) の世界 が開拓を待つていることを忘れてはならない，通産省の 次世代産業基盤技術確立施策に見るごとく,80 年代は材 料の時代であるが，それにふさわしい言葉をあげて本稿 の結びとしたい13).

"Engineering is a combination of brains and materials, the more brains the less materials". (Kettering)

\section{交献}

1) 大沢 恂：自動車技術，34 (1980) 7, p. 819

2 ) 昭和 53 年高機能樹脂需要構造調査報告書, 昭555 , 通産省基礎産業局

3 ) 島村昭治：プラスチックス，30（昭54）9， p. 11

4 ) プラスチック実用試験ハンドブック（プラスチッ ク標準試験方法研究会)，(1981)，p. 261[工業調 查会]

5) SAE Paper 750957 による

6) L. E. Morvison: SPI, RPGI, 35 (1980-2), U. S. Status Peport

7 ) R. L. Daugherty: Japan-U. S. Conf, Comp. Mater., (Jan. 12-14, '81).

8 ) Chevrolet News, 1980-2-7

9) S. Shimamura: SPI, RPGI, 25 (1970), 7-D および強化プラスチックス，(1979-9)

10) 田辺，ほか：自動車技術会春季講演大会 $(1980-5)$ p. 187

11) 日経メカニカル，(1980-3-31)，p. 70

12) 自動車(プラスチックの市場と商品設計), (1980) p. 91 [プラスチックェージ]

13）島村昭治：自動車技術，34（1980）7，p. 803 